\title{
Effects of Indian lilac (Melia azedarach L.) extract fractions against resilient documented hospital pathogens
}

Khushnood Ur Rehman ${ }^{1 *}$, Muhammad Hamayun ${ }^{2}$, Tabassum Yaseen ${ }^{3}$, Saqib Ullah ${ }^{1}$, Asad Ali Khan ${ }^{1}$, Muhammad Noor ${ }^{4}$ and Shahab Saeed $\mathrm{Khan}^{1}$

1. Department of Botany, Islamia College Peshawar-Pakistan

2. Department of Botany, Abdul Wali Khan University Mardan-Pakistan

3. Department of Botany, Bacha Khan University Charsadda-Pakistan

4. Department of Agriculture, Hazara University, Khyber Pakhtunkhwa, Pakistan.

*Corresponding author's email: drkhushnood@icp.edu.pk

Citation

Khushnood Ur Rehman, Muhammad Hamayun, Tabassum Yaseen, Saqib Ullah, Asad Ali Khan, Muhammad Noor and Shahab Saeed Khan. Effects of Indian lilac (Melia azedarach L.) extract fractions against resilient documented hospital pathogens. Pure and Applied Biology. Vol. 10, Issue 4, pp995-1003.

http://dx.doi.org/10.19045/bspab.2021.100104

Received: 24/08/2020 Revised: 20/12/2020

Accepted: 30/12/2020

Online First: 07/01/2021

\section{Abstract}

A plant's response to the pioneer biological activities is the first step that it is used for therapeutic purposes. The antibacterial and antifungal properties of Melia azedarach L. (Indian Lilac) were investigated. As Indian Lilac is known for centuries as an antibacterial and antifungal agent, the main purpose of this study was to find is it effective against the most resilient human bacterial and fungal pathogens, which were collected from the different hospitals of Khyber Pakhtunkhwa. The crude extract was fractionated into five parts i.e. aqueous, chloroform, crude methanolic, ethyl acetate, and n-hexane. The fractions were then checked against most resistant strains of bacteria and fungi i.e. MRSA (Methicilline resistance Staphylococcus aurous), Serratia marcescense, Staphylococcus aurous, and Streptococcus mutans, for antibacterial activity and Alternaria alternate, Aspergillus flavous, Fusarium oxysporum, and polyspondylium pallidum for antifungal activity. Among all fractions, ethyl acetate was most effective against the selected pathogens showing the activity of i.e. (61-39\%) and lowermost effectiveness shown by an aqueous fraction (47-30\%) for bacterial pathogens. Regarding the antifungal activity, the most effective fraction was crude methanolic extracts (65-30\%), and the least effective was fractions (20-10\%). While the effectiveness of other selected fractions was in between the two. In conclusions of our experimentation, it is intensely supported, that Melia azedarach L. is even significant against most resilient strains of bacteria and fungi.

Keywords: Antibacterial; antifungal; antimicrobial; Indian Lilac; Melia azedarach

Introduction The use of plants as traditional medicine had been dated since the arrival of humans on planet earth. Humans have no other options in case of their diseases but to utilize either plants or animals for cure purposes. Men of ancient times used plants for food and as traditional medicines but with time and advancements, the usage has been 
improved as well. E.g. traditional and indigenous knowledge is slowly replaced by homeopathic and allopathic medicines $[1,2]$. People belonging to different religions and living in different parts of the world used plants for treatment purposes independently. Almost three by fourth parts of plants have specific compounds that can cure a wide range of diseases [3, 4]. These compounds are the result of secondary metabolism and mostly include alkaloids, glycosides, terpenoids, flavonoids, saponins, tannins, and amino acids, etc. which can fight germs in the animal body and can cause deterioration against them. The discoveries transpired mainly in two disciplines i.e. science and technology in the last centuries had enabled the scientists to perform more accurate and advanced experiments which on success-ding produce new natural and synthetic drugs helping to reduce and eradicate various diseases. According to the WHO (world health organization), the annual death rate occurring throughout the world is mainly contributed by infectious diseases and in tropical countries, it may reach up to $50 \%$. Reports disclosed that developing countries still rely on indigenous knowledge of plants and use $80 \%$ medicinal plants as therapeutic agents against numerous human diseases [5, 6]. Due to such shortcomings, scientists and researchers started working to process and develop safe herbal medicines and to isolate active therapeutic compounds used in both herbal and derived medicines to cope with germs $[7,8]$.

Melia azedarach $L$. an active therapeutic compound containing a plant appearing like a tree with 15-25-meter height with deciduous nature having dense canopy cover [9, 10]. It has its place in the family Meliaceae and it has originated from lower and humid countries of Asia [11, 12]. Its distribution is cosmopolitan regarding tropical countries and the areas of various countries falling in the tropical zone; however, it also prevails in sub-tropical regions as well. Different vernacular names of this medicinal plant also exist as used in traditional medicinal purposes long ago, so it can be called Chinaberry, Persian lilac, Tulip cedar, and white cedar $[13,14] . \quad$ Its use in indigenous and traditional systems of medicines from past decades reveals its medicinal properties and with advanced scientific researches, it has proven to stop malaria, cancer, inflammation, stomachache, and analgesic up to a certain extent. Similarly, it can be utilized as a diuretic, astringent, and anthelmintic as well. In the focused experiment, five different solvents have been used to dissolve parts used of $M$. azedarach and were checked against four bacterial and four fungal strains respectively to investigate the anti-microbial activity.

\section{Material and Methods}

Antibacterial activity

\section{Collection and processing of plant specimen}

Several visits have been conducted to different areas of the Khyber Pakhtunkhwa for the collection of Melia azedarach $\mathrm{L}$. The collected plant material was rinsed and dried in shadow after which it was dried in an oven. The fully dried plant parts were pulverized by using a grinder. Then the powder is stored at a cool place before extraction.

\section{Preparation of extraction and fractions}

The cold maceration method was used for the extraction of the active metabolites. One and half of the powdered plant material were dipped in two later of ethanol and incubated for 5 days at $40^{\circ} \mathrm{C}$. The material filtered thrice and a clear filtrate was obtained. The filtrate was subjected to evaporation via a rotary evaporator at $40^{\circ} \mathrm{c}$. The obtained extract was dried and then dissolved in $100 \mathrm{ml}$ distilled water. The solution was the fractionate of dissimilar diluents comprising methanol, n-hexane ethanol, ethyl acetate, and chloroform by using a separating funnel. All the fractions thus obtained were 
concentrated by rotary evaporator and designate for that solvent fraction.

\section{Media preparation}

The anti-bacterial activity in this experiment was checked by the agar well diffusion method. One liter of distilled water was used to liquefy $25 \mathrm{~g}$ of Luria Both, $\mathrm{PH}$ of Miller powder was put at 7.0. The media put in an autoclave in a $250 \mathrm{ml}$ flask. The selected four bacterial strains were introduced into the flask and kept overnight at 150RPM at $37^{\circ} \mathrm{C}$. After that agar was converted into solid form, five holes were excavated into the agar through a borer. The inoculum was introduced into the tunnel. The bacterial and fungal species were selected due to their frequent occurrence in local hospitals of Khyber Pakhtunkhwa (KPK) and also showing resistance to different drugs.

\section{Test for bacterial strains}

Among the four selected bacterial strains, three were gram-positive and one strain is gram-negative i.e MRSA (Methicillin resistance staphylococcus aurous), Streptococcus mutans, and Staphylococcus aurous. And the gram-negative is Serratia marcescens.

\section{Measurement of zones of inhibition}

Dimethyl sulfoxide $20 \mathrm{mg} / \mathrm{ml}$ had been utilized as a negative control in which acted as a solvent. Cefotaxime (standard antibiotics) was used as a positive controller. The plant fractions of about $75 \mu \mathrm{l}$ were introduced into the wells of the petri dish and the Petri dishes were retained at $37^{\circ} \mathrm{c}$ in the incubator for 24 hours. When the incubation period was completed then the growth area of each transparent region was analyzed. The analyses were repeated thrice to calculate the standard data $[7,8]$.

\section{Test for fungal strains}

During the antifungal activity, the four fungal strains were selected i.e Fusarium oxysporum, Aspergillus flavous, polyspondylium pallidum, and Alternaria alternate.

\section{Statistical analysis}

The statical analysis was done through Excel MS Office 2013 while ANOVA were done through Excel two factor variation without replication.

\section{Results}

\section{Antibacterial activity of Melia azedarach} L.

Regarding check the effectiveness of Melia azedarach L. as an anti-bacterial agent, five fractions were utilized and four bacterial strains i.e. Streptococcus mutans, Staphylococcus aurous, MRSA (Methicilline resistance Staphylococcus aurous), and Serratia marcescense were analyzed. The selection of these species for experimental purposes is because of their pathogenic nature and the pathogen are reported frequently during the investigation from hospitals of Khyber Pakhtunkhwa. All these species are the causative agent for different human diseases and therefore we tested our extracts against these pathogenic species to determine their pathogenicity and find out cheap and efficacious treatment against these bacterial strains. Results shown in the table revealed the effectiveness of all the fractions by taking $6 \mathrm{mg} / \mathrm{ml}$ of selected and checked crude fraction of plant against the observed bacterial strains.

\section{Antibacterial potential of the crude extract of Melia Azedarach}

Crude methanolic extract inhibited the growth of MRSA with highest percentage of $52 \%$ followed by $S$. marcescens up to $47 \%$, $S$. aureus with $46 \%$, and $S$. mutans up to $39 \%$. $n$-hexane fraction highly repressed the growth of S. marcescens with 52\% which was followed by MRSA with $40 \%, S$. mutans, and S. aureus with $35 \%$ and $34 \%$ respectively. The chloroform fraction was found to be the most active extract which showed the highest activity against the $S$. marcescens with $61 \%$ while its lowest activity is observed against S. aureus with $38 \%$. In Ethyl acetate fraction the growth 
inhibition was recorded in order of $S$. marcescens (52\%), S. aureus (46\%), MRSA (44\%), and S. mutans (32\%) respectively. The aqueous extracted fraction inhibited the growth of $S$. marcescens with the highest inhibition zone $(10.0 \pm 0.54 \mathrm{~mm}$ zone and $47 \%$ ) while in the same fraction the lowest efficacy was obtained for $S$. aureus which is up to $30 \%$. See (Table 1, 2; Fig. 1).

Table 1. Antibacterial Potential of the Crude Extract of $M$. Azedarach

\begin{tabular}{|c|c|c|c|c|c|c|c|c|c|c|c|}
\hline \multirow{2}{*}{ Bacteria $\mathrm{K} 2$} & \multirow{2}{*}{ Standard } & \multicolumn{2}{|c|}{ Cr. Met. Ext } & \multicolumn{2}{|c|}{$n$ - hexane } & \multicolumn{2}{|c|}{$\mathrm{CHCl}_{3}$} & \multicolumn{2}{|c|}{ EtOAc } & \multicolumn{2}{|c|}{ Aqueous } \\
\hline & & Zone & $\%$ & Zone & $\%$ & Zone & $\%$ & Zone & $\%$ & Zone & $\%$ \\
\hline 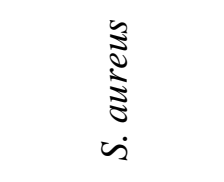 & $\begin{array}{l}+ \\
\tilde{o} \\
0 \\
0 \\
0 \\
\dot{0}\end{array}$ & $\begin{array}{l}\hat{\sigma} \\
0 \\
0 \\
0 \\
\dot{1} \\
\text { I }\end{array}$ & $\frac{n}{6}$ & $\begin{array}{l}m \\
m \\
0 \\
+1 \\
0 \\
\dot{0}\end{array}$ & $\begin{array}{l}\text { ర్} \\
\underset{\dot{d}}{ }\end{array}$ & $\begin{array}{l}0 \\
\vdots \\
0 \\
+1 \\
0 \\
0\end{array}$ & $\begin{array}{l}0 \\
+ \\
\infty \\
\infty \\
m\end{array}$ & $\begin{array}{l}n \\
n \\
0 \\
+1 \\
i \\
\end{array}$ & $\frac{n}{\dot{0}}$ & $\begin{array}{l}0 \\
n \\
0 \\
+1 \\
0 \\
0 \\
0\end{array}$ & $\stackrel{\hat{\theta}}{\dot{0}}$ \\
\hline 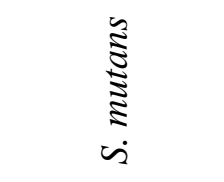 & $\begin{array}{l}\stackrel{n}{f} \\
0 \\
+1 \\
0 \\
\infty \\
\infty \\
\end{array}$ & $\begin{array}{l}0 \\
n \\
0 \\
+1 \\
0 \\
=\end{array}$ & $\begin{array}{l}\text { సे } \\
\text { กे }\end{array}$ & $\begin{array}{l}n \\
n \\
0 \\
+1 \\
0 \\
0\end{array}$ & $\vec{r}$ & $\begin{array}{l}m \\
\vdots \\
0 \\
+1 \\
\dot{0}\end{array}$ & $\begin{array}{l}\stackrel{m}{f} \\
\dot{f}\end{array}$ & $\begin{array}{l}\text { + } \\
\dot{0} \\
+1 \\
\dot{+} \\
\dot{0}\end{array}$ & $\frac{\Xi}{\sim}$ & $\begin{array}{l}n \\
\tilde{0} \\
0 \\
+1 \\
0 \\
8\end{array}$ & $\begin{array}{l}\text { 巳 } \\
\text { ஸे }\end{array}$ \\
\hline 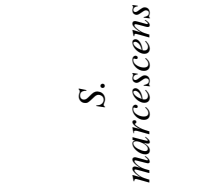 & 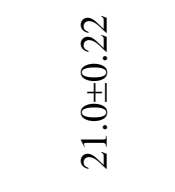 & $\begin{array}{l}0 \\
n \\
0 \\
+1 \\
0 \\
0\end{array}$ & \begin{tabular}{l} 
ర్ \\
\multirow{\gamma}{*}{}
\end{tabular} & $\begin{array}{l}\stackrel{n}{+} \\
0 \\
+1 \\
0 \\
=\end{array}$ & $\begin{array}{l}\infty \\
\sim \\
\sim \\
n\end{array}$ & \begin{tabular}{l}
$n$ \\
\multirow{0}{0}{} \\
+1 \\
0 \\
$\dot{0}$ \\
\end{tabular} & $\frac{8}{6}$ & \begin{tabular}{l}
\multirow{J}{\pm}{} \\
$\dot{0}$ \\
+1 \\
0 \\
$=$
\end{tabular} & $\begin{array}{l}\infty \\
\sim \\
n \\
n\end{array}$ & \begin{tabular}{l}
\multirow{2}{n}{} \\
0 \\
+1 \\
0 \\
0 \\
0
\end{tabular} & $\begin{array}{l}\sigma \\
\sigma \\
\forall\end{array}$ \\
\hline $\begin{array}{l}\mathbb{\widetilde { n }} \\
\stackrel{2}{\Sigma}\end{array}$ & 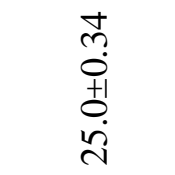 & $\begin{array}{l}n \\
n \\
0 \\
0 \\
0 \\
\dot{m}\end{array}$ & $\begin{array}{l}8 \\
\text { in } \\
\text { nิ }\end{array}$ & $\begin{array}{l}n \\
0 \\
0 \\
+1 \\
0 \\
0\end{array}$ & $\begin{array}{l}8 \\
\stackrel{8}{+} \\
\dot{0}\end{array}$ & $\begin{array}{l}n \\
0 \\
0 \\
+1 \\
0 \\
=\end{array}$ & $\begin{array}{l}8 \\
8 \\
\dot{J}\end{array}$ & $\begin{array}{l}+ \\
0 \\
0 \\
+1 \\
0 \\
0\end{array}$ & $\begin{array}{l}8 \\
8 \\
\dot{8}\end{array}$ & $\begin{array}{l}0 \\
0 \\
0 \\
+1 \\
0 \\
0\end{array}$ & $\begin{array}{l}8 \\
8 \\
\stackrel{8}{0}\end{array}$ \\
\hline
\end{tabular}

Table 2. ANOVA (two factors) of antibacterial potential of M. azedarach

\begin{tabular}{|c|c|c|c|c|c|c|}
\hline Summary & Count & Sum & Average & \multicolumn{3}{|c|}{ Variance } \\
\hline S. aureus & 6 & 77 & 12.83333 & \multicolumn{3}{|c|}{44.16667} \\
\hline S. mutans & 6 & 80 & 13.33333 & \multicolumn{3}{|c|}{53.86667} \\
\hline S. marcescens & 6 & 76 & 12.66667 & \multicolumn{3}{|c|}{17.86667} \\
\hline MRSA & 6 & 80 & 13.33333 & \multicolumn{3}{|c|}{33.86667} \\
\hline Standard & 4 & 100 & 25 & \multicolumn{3}{|c|}{8.666667} \\
\hline Cr. Met. Ext & 4 & 46 & 11.5 & \multicolumn{3}{|c|}{1.666667} \\
\hline n- hexane & 4 & 40 & 10 & \multicolumn{3}{|c|}{0.666667} \\
\hline $\mathrm{CHCl} 3$ & 4 & 47 & 11.75 & \multicolumn{3}{|c|}{2.25} \\
\hline EtOAc & 4 & 43 & 10.75 & \multicolumn{3}{|c|}{1.583333} \\
\hline Aqueous & 4 & 37 & 9.25 & \multicolumn{3}{|c|}{0.916667} \\
\hline \multicolumn{7}{|l|}{ ANOVA } \\
\hline Source of Variation & SS & df & MS & $\mathbf{F}$ & P-value & F crit \\
\hline Rows & 2.125 & 3 & 0.708333 & 0.235457 & 0.870249 & 3.287382 \\
\hline Columns & 703.7083 & 5 & 140.7417 & 46.78393 & $1.27 \mathrm{E}-08$ & 2.901295 \\
\hline Error & 45.125 & 15 & 3.008333 & - & - & - \\
\hline Total & 750.9583 & 23 & & - & - & - \\
\hline
\end{tabular}




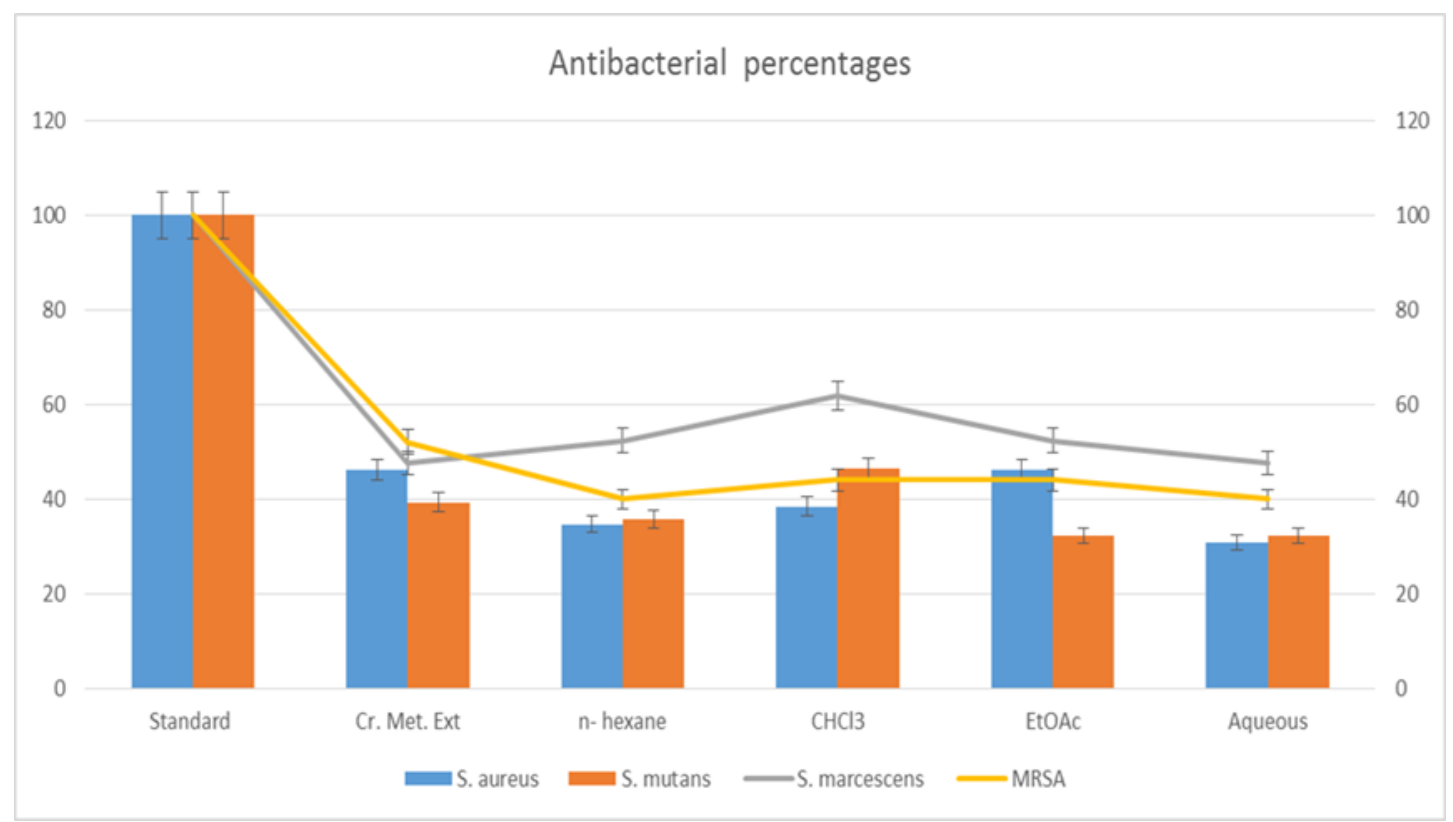

Figure 1. Antibacterial activity of Melia azedarach

Anti-fungal activity of Melia azedarach $\mathbf{L}$. Four fungal strains i.e. Fusarium oxysporum, Aspergillus flavous, Polyspondylium pallidum and Alternaria alternate were utilized to obtain the efficacy of the plant in five different solvents. The overall results of anti-fungal activities were significant except for aqueous extract. Crude methanolic extract proved to be very resistant against $A$. alternate and prevented its growth up to $65 \%$ followed by $P$. pallidum with $55 \%$ and was least resistant against $F$. oxysporum with $30 \%$. N-hexane fraction repressed the growth of $P$. pallidum with $60 \%$ followed by $A$. flavous with $50 \%$, A. alternate with $45 \%$, and $F$. oxysporum with $40 \%$ which is the least for this fraction. Chloroform proved to be most active against $A$. alternate and prevented the growth of said fungus with the highest percentage up to $60 \%$, followed by $P$. pallidum with $55 \%$, A. flavous with $45 \%$, and was least active against $F$. oxysporum $40 \%$ respectively. A. alternate was also sensitive to ethyl acetate as well and was stopped by the fraction up to $55 \%$, for which $P$. pallidum and $A$. flavous fall second each with $40 \%$, and F. oxysporum was slightest sensitive with $35 \%$. The aqueous extract was less active against all fungal lines, and its effectiveness was greater against A. flavous with $20 \%$ following A. alternate and F. oxysporum with $15 \%$ each and $P$. pallidum with $10 \%$ respectively. See (Table 3, 4; Fig. 2). From the above experiment, it is quite clear that Alternaria alternate and Polyspondylium pallidum appeared to be the most affected species by the action of extracts. 
Table 3. Anti-fungal activity of Melia azedarach $L$.

\begin{tabular}{|c|c|c|c|c|c|c|c|c|c|c|c|}
\hline \multirow{2}{*}{ Fungi } & \multirow{2}{*}{ Standard } & \multicolumn{2}{|c|}{ Cr. Met. Ext } & \multicolumn{2}{|c|}{$n$-hexane } & \multicolumn{2}{|c|}{$\mathrm{CHCl}_{3}$} & \multicolumn{2}{|c|}{ EtOAc } & \multicolumn{2}{|c|}{ Aqueous } \\
\hline & & Area & $\%$ & Area & $\%$ & Area & $\%$ & Area & $\%$ & Area & $\%$ \\
\hline$\frac{\dot{\pi}}{\frac{3}{\sqrt{3}}}$ & $\begin{array}{l}8 \\
8 \\
0 \\
+1 \\
0 \\
8 \\
8\end{array}$ & 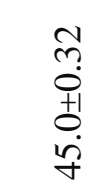 & $\begin{array}{l}8 \\
\stackrel{8}{7}\end{array}$ & $\begin{array}{l}2 \\
\text { ○े } \\
+1 \\
\dot{0} \\
\dot{0}\end{array}$ & $\begin{array}{l}8 \\
8 \\
\circ \\
\circ\end{array}$ & 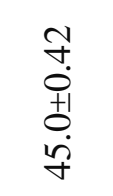 & $\begin{array}{l}8 \\
\stackrel{8}{f}\end{array}$ & $\begin{array}{l}\text { fo } \\
\dot{0} \\
+1 \\
\dot{0} \\
\dot{+}\end{array}$ & $\begin{array}{l}8 \\
\stackrel{8}{+}\end{array}$ & $\begin{array}{l}\text { N } \\
\dot{0} \\
+1 \\
\dot{0} \\
\stackrel{0}{0}\end{array}$ & 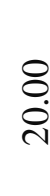 \\
\hline 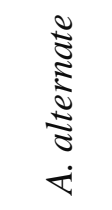 & $\begin{array}{l}8 \\
8 \\
0 \\
01 \\
0 \\
8 \\
8\end{array}$ & \begin{tabular}{l}
$f$ \\
\multirow{0}{*}{} \\
0 \\
+1 \\
0 \\
$\ddot{6}$
\end{tabular} & $\begin{array}{l}8 \\
6 \\
6\end{array}$ & $\begin{array}{l}\hat{a} \\
\dot{0} \\
+1 \\
0 \\
\dot{y}\end{array}$ & $\begin{array}{l}8 \\
\dot{\gamma} \\
\dot{\gamma}\end{array}$ & 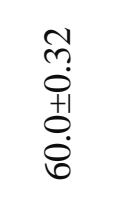 & $\begin{array}{l}8 \\
8 \\
8\end{array}$ & $\begin{array}{l}0 \\
n \\
0 \\
+1 \\
0 \\
n \\
n\end{array}$ & $\begin{array}{l}8 \\
i n \\
i n\end{array}$ & 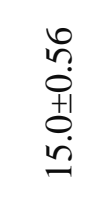 & 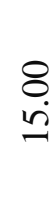 \\
\hline 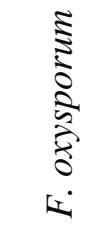 & $\begin{array}{l}8 \\
8 \\
0 \\
+1 \\
0 \\
\dot{8}\end{array}$ & $\begin{array}{l}\hat{\sigma} \\
0 \\
+1 \\
0 \\
0 \\
0\end{array}$ & $\begin{array}{l}8 \\
\text { ¿ } \\
\text { ¿ }\end{array}$ & 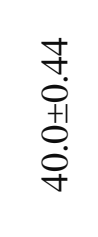 & $\begin{array}{l}8 \\
\stackrel{8}{+}\end{array}$ & $\begin{array}{l}\bar{\sim} \\
0 \\
0 \\
+ \\
0 \\
\dot{+}\end{array}$ & $\begin{array}{l}8 \\
\stackrel{8}{+}\end{array}$ & $\begin{array}{l}\text { જे } \\
0 \\
+1 \\
0 \\
\dot{0}\end{array}$ & $\begin{array}{l}8 \\
\dot{n} \\
\dot{m}\end{array}$ & $\begin{array}{l}\infty \\
\stackrel{0}{0} \\
0 \\
0 \\
0 \\
\end{array}$ & $\begin{array}{l}8 \\
\qquad \\
\end{array}$ \\
\hline 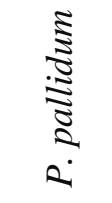 & $\begin{array}{l}8 \\
8 \\
0 \\
+1 \\
0 \\
8 \\
8\end{array}$ & $\begin{array}{l}0 \\
0 \\
0 \\
+1 \\
0 \\
\dot{1} \\
n\end{array}$ & $\begin{array}{l}8 \\
i n \\
n\end{array}$ & $\begin{array}{l}0 \\
n \\
0 \\
+1 \\
0 \\
0 \\
0\end{array}$ & $\begin{array}{l}8 \\
8 \\
8\end{array}$ & 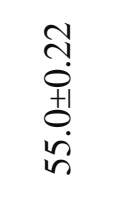 & $\begin{array}{l}8 \\
0 \\
i n\end{array}$ & $\begin{array}{l}0 \\
n \\
0 \\
+1 \\
+ \\
0 \\
\dot{+}\end{array}$ & $\begin{array}{l}8 \\
\stackrel{8}{\circ} \\
\stackrel{+}{0}\end{array}$ & $\begin{array}{l}\infty \\
ٌ \\
0 \\
+1 \\
0 \\
0\end{array}$ & $\begin{array}{l}8 \\
8\end{array}$ \\
\hline
\end{tabular}

Table 4. ANOVA (two factors) of Antifungal Potential of M. Azedarach

\begin{tabular}{|c|c|c|c|c|c|c|}
\hline Summary & Count & Sum & Average & \multicolumn{3}{|c|}{ Variance } \\
\hline A.flavus & 6 & 300 & 50 & \multicolumn{3}{|c|}{710} \\
\hline A. alternate & 6 & 340 & 56.66667 & \multicolumn{3}{|c|}{766.6667} \\
\hline F. oxysporum & 6 & 260 & 43.33333 & \multicolumn{3}{|c|}{856.6667} \\
\hline P. pallidum & 6 & 320 & 53.33333 & \multicolumn{3}{|c|}{856.6667} \\
\hline Standard & 4 & 400 & 100 & \multicolumn{3}{|c|}{0} \\
\hline Cr. Met. Ext & 4 & 195 & 48.75 & \multicolumn{3}{|c|}{222.9167} \\
\hline n- hexane & 4 & 195 & 48.75 & \multicolumn{3}{|c|}{72.91667} \\
\hline $\mathrm{CHCl} 3$ & 4 & 200 & 50 & \multicolumn{3}{|c|}{83.33333} \\
\hline EtOAc & 4 & 170 & 42.5 & \multicolumn{3}{|c|}{75} \\
\hline Aqueous & 4 & 60 & 15 & \multicolumn{3}{|c|}{16.66667} \\
\hline \multicolumn{7}{|l|}{ ANOVA } \\
\hline Source of Variation & SS & Df & MS & $\mathbf{F}$ & P-value & F crit \\
\hline Rows & 583.3333 & 3 & 194.4444 & 3.517588 & 0.041343 & 3.287382 \\
\hline Columns & 15120.83 & 5 & 3024.167 & 54.70854 & $4.24 \mathrm{E}-09$ & 2.901295 \\
\hline Error & 829.1667 & 15 & 55.27778 & - & - & - \\
\hline Total & 16533.33 & 23 & & - & - & - \\
\hline
\end{tabular}




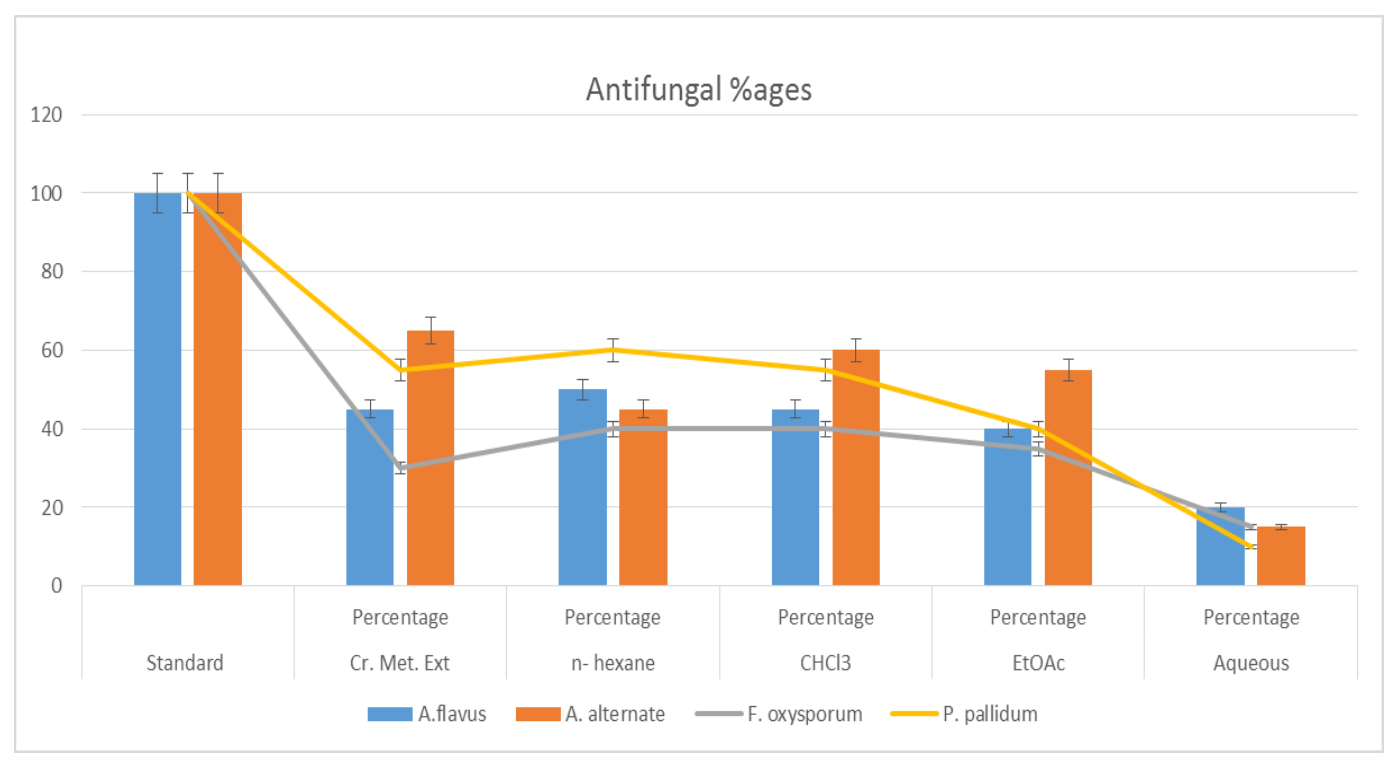

Figure 2. Antifungal Activity of Melia azedarach

\section{Discussion}

Medicinal plants are used against microbial species for many centuries and are a usual practice for the human being. These antimicrobial tests have been carried out at a regular interval of time because it produces useful compounds that prevent their pathogenic activity. Among the microbial pathogens, Bacteria and Fungi have the most disastrous impact on the health of plants and are contagious to animals resulting in huge yearly damages to crops, harmful effects on quality control, and reducing storing capabilities of cultivated crops. To deal with such kinds of fatal pathogens, active ingredients from plant or natural sources become the utmost importance of the modern era $[15,16]$. These adaptable fungi when gets entry the human body result in several diseases that can be fatal but they can be prevented by medicines having no side effects [17]. For developing such natural drugs medicinal plants are the main spotlight [18, 19]. Plants contain several active compounds that have been separated before and resulted in effective prevention against different diseases. As the knowledge of plants along with their discoveries increases, the value of drugs from plant's origin also increases and is at a peak due to their negligible side effects as compared to allopathic medicines. In the emerging areas of the world, the standards and quantity of allopathic and laboratory prepared drugs are less than their demands $[20,21]$, also the prices of these synthetic drugs are far from accessibility, for those people plants can be the ultimate solution because of its cheapness and no extra effects. Indigenous knowledge of medicinal plants is still an important way to cure diseases and is used in developing next-level drugs and chemical substances to interact with new diseases regarding safety $[22,23]$. In this attempt, a medicinal plant i.e. Melia azedarach was applied in five fractions (Crude methanolic extract, nHexane, trichloromethane, ethyl acetate, and Aqueous extract) and optimized against four pathogenic bacteria (Staphylococcus mutans, Serratia marcescens, MRSA, and Streptococcus aureus) and fungal strains (Fusarium oxysporum, Aspergillus flavous, 
Polysphondylium pallidum and Alternaria alternate) collected from hospitals of Khyber Pakhtunkhwa.

The plant extract in all solvents exhibited significant action against both pathogenic lines. S. marcescens and MRSA exhibited to be very sensitive against the plant extracts in different solvents regarding bacterial strains while $S$. mutans and $S$. aureus shows resistance to some extent but still these results can be prominent by increasing the concentration of extracts which is in agreement with [24, 25].

\section{Conclusion}

The overall antifungal activity was notable and significant except only aqueous extract which seems not to affect the growth of fungal strains. Polysphondylium pallidum and Alternaria alternate showed less resistance and were affected by the plant's extracts in all solvents and their average activity falls between $45 \%$ to $65 \%$. Fusarium oxysporum and Aspergillus flavous showed high resistance and their average percentage also falls low. The overall results were very significant with $\mathrm{p}$-value for antibacterial activity $=1.57 \times 10^{-06}$ and $\mathrm{p}=1.19 \mathrm{X} 10^{-07}$ for antifungal activities.

\section{Authors' contributions}

Conceived and designed the experiments: $\mathrm{M}$ Hamayun, Performed the experiments: $M$ Hamayun, $\mathrm{T}$ Yaseen \& KU Rehman, Analyzed the data: KU Rehman \& S Ullah, Contributed materials/ analysis/tools: M Noor \& AA Khan, Wrote the paper: KU Rehman, S Ullah \& SS Khan.

\section{References}

1. Wali S, ur Rehman K, Ullah B, Yaseen T \& Ahmad G (2019). 8. Efficiency of common water hyacinth (eichhornia crassipes) in controlling growth of fungal and bacterial clinical strains. Pure and Appl Biol 8(4): 2178-2186.

2. Khushnood ur Rehman SW, Akhtar N, Ullah B, Afzal S, Ahmad I \& Hamayun M (2019). 18. Evaluation of the antibacterial and antifungal potential of spider saxifrage plant (saxifraga flagellaris willd.). Pure and Appl Biol 8(2): 1163-1171.

3. Khan SA, Hamayun M, Yoon $\mathrm{H}$ et al. (2008). Plant growth promotion and penicillium citrinum. BMC Microbial 8(1): 1-10.

4. Pichersky E \& Gershenzon J (2002). The formation and function of plant volatiles: Perfumes for pollinator attraction and defense. Current Opi in plant Biol 5(3): 237-243.

5. Schantz-Dunn J \& Nour NM (2009). Malaria and pregnancy: A global health perspective. Rev in Obstetrics and Gynecol 2(3): 186.

6. Rehman KU, Hamayun M, Khan SA, Khan SS \& Wali S (2020). Competence of benzoil tree (moringa oleifera 1.) as antibacterial and antifungal agent. Advancements in Life Sci 7(3): 135-139.

7. Verma S \& Singh S (2008). Current and future status of herbal medicines. Veterinary world 1(11): 347.

8. Bent S \& Ko R (2004). Commonly used herbal medicines in the United States: A review. The Am J of Med 116(7): 478485.

9. Sen A \& Batra A (2012). Evaluation of antimicrobial activity of different solvent extracts of medicinal plant: Melia azedarach 1. Int J Curr Pharm Res 4(2): 67-73.

10. Hussain SA, Ahmad S, Butt ZA, Rehman KU, Ullah S \& Khan SS. (2020). Flavonoids, alkaloids, and saponins as antimicrobial agents from fragaria vesca 1. Pure and Appl Boil 10(3): 761-769.

11. Koenen EJ, Clarkson JJ, Pennington TD \& Chatrou LW (2015). Recently evolved diversity and convergent radiations of rainforest mahoganies (meliaceae) shed new light on the origins of rainforest 
hyperdiversity. New Phytologist 207(2): 327-339.

12. Talukder F \& Howse P (1993). Deterrent and insecticidal effects of extracts of pithraj, aphanamixis polystachya (meliaceae), againsttribolium castaneum in storage. J of Chem Ecol 19(11): 24632471.

13. Al-Rubae AY (2009). The potential uses of melia azedarach 1. As pesticidal and medicinal plant, review. American-Eur J of Sustainable Agric 3(2): 185-194.

14. Bhagwat VC \& Kadam VB Studies on phytochemical constituents of azadirachta indica a. Juss. And melia azedarach linn.

15. Khatoon A, Jethi S, Nayak SK, Sahoo S, Mohapatra A \& Satapathy KB (2014). Evaluation of in vitro antibacterial and antioxidant activities of melia azedarach 1. Bark. IOSR J of Pharm and Biol Sci 9(6): 14-17.

16. Joray MB, del Rollán MR, Ruiz GM, Palacios SM \& Carpinella MC (2011). Antibacterial activity of extracts from plants of central argentina-isolation of an active principle from achyrocline satureioides. Planta Medi 77(01): 95100.

17. Zahoor M, Ahmed M, Naz S \& Ayaz M (2015). Cytotoxic, antibacterial and antioxidant activities of extracts of the bark of melia azedarach (china berry). Natural Product Res 29(12): 1170-1172.

18. Sasidharan S, Chen Y, Saravanan D, Sundram K \& Latha LY (2011). Extraction, isolation and characterization of bioactive compounds from plants' extracts. African $J$ of Traditional, Complementary and Alternative Med 8(1):

19. Sultana S, Asif HM, Akhtar N, Waqas M \& Rehman SU (2014). Comprehensive review on ethanobotanical uses, phytochemistry and pharmacological properties of melia azedarach linn. Asian J of Pharma Res and Health Care 6(1):

20. Gurib-Fakim A (2006). Medicinal plants: Traditions of yesterday and drugs of tomorrow. Mol Aspects of Med 27(1): $1-93$.

21. Carpinella MC, Ferrayoli CG \& Palacios SM (2005). Antifungal synergistic effect of scopoletin, a hydroxycoumarin isolated from melia azedarach 1 . Fruits. $J$ of Agric and Food Chem 53(8): 29222927.

22. Carpinella MaC, Herrero GG, Alonso RA \& Palacios SM (1999). Antifungal activity of melia azedarach fruit extract. Fitoterapia 70(3): 296-298.

23. Marino G, Gaggìa F, Baffoni L, Toniolo C \& Nicoletti M (2015). Antimicrobial activity of melia azedarach fruit extracts for control of bacteria in inoculated invitro shoots of ' $m$ rs $2 / 5$ 'plum hybrid and calla lily and extract influence on the shoot cultures. Eur J of Plant Pathol 141(3): 505-521.

24. Ur-Rehman K, Hamayun M, Khan SA, Iqbal A \& Hussain A (2019). Heavy metal analysis of locally available anticancer medicinal plants. Biosciences Biotechnology Research Asia 16(1): 105-111.

25. Pandey A \& Agnihotri V (2015). Antimicrobials from medicinal plants: Research initiatives, challenges, and the future prospects. Biotechnology of Bioactive Compounds: Sources and Applications in Food and Pharmaceuticals, John Wiley \& Sons, Ltd: 123-150. 